\title{
Plant Growth Promoting Potential and Biocontrol Efficiency of Phosphate Solubilizing Bacteria in Rice (Oryza sativa L.)
}

\author{
Pratibha Rawat, Deepti Shankhdhar and S. C. Shankhdhar*
}

Department of Plant Physiology, College of Basic Sciences \& Humanities, G. B. Pant University of Agriculture \& Technology, Pantnagar, Uttarakhand, India

*Corresponding author

\begin{abstract}
A B S T R A C T
Keywords

Phosphorus,

Phosphate

solubilizing

bacteria, Biocontrol,

Growth

Article Info

Accepted:

17 August 2020

Available Online:

10 September 2020

To study the impact of phosphate solubilizing bacteria (PSB) and phosphorus fertilizer rates on growth parameters and pest infestation in rice, a field experiment for two successive years (2018 and 2019) was laid out in split- plot design with nine treatments viz. uninoculated control with different phosphate fertilizer doses viz., 0\%, 50\%, 75\%, and $100 \%$ recommended dose (T1), PSB1 (T2), PSB2 (T3) PSB3 (T4), PSB1 + PSB2 (T5), PSB1 + PSB3 (T6), PSB2 + PSB3 (T7), PSB1 + PSB2 + PSB3 (T8), and Standard PSB (T9). The results significantly validated positive correlation between PSB inoculation and the growth attributes such as stem weight, leaf weight, and productive tiller number per hill at flowering. Growth parameters enhanced significantly when treated with PSB and $50 \%$ fertilizer dose. Percentage of stem borer and leaf folder infestation in PSB treated plants blended with $50 \%$ phosphate fertilization reduced significantly compared to control plants for both the cropping years. It can be concluded from our study that optimum dose of phosphate fertilizer (50\% recommended dose) in combination with PSB could be an effective strategy to promote rice growth and development in an ecofriendly and sustainable manner.
\end{abstract}

\section{Introduction}

Rice is a global food grain consumed by half of the world's seven billion people. Almost $60 \%$ of rice is consumed by humans in Southeast Asia. Rice provides $15 \%$ per capita protein and $21 \%$ global human per capita energy (IRRI, 2006). With an approximate increase in world population from 6.2 billion in 2000 to 8.2 billion in 2030 global rice demand will rise to about 765 million tonnes (FAO, 2019). In India, total rice production in
2018 was estimated to be 99.24 million tonnes which was higher by 1.74 million tonnes than the last year's production of 97.50 million tonnes (FAO, 2018).

The world rice utilization is forecasted to outreach 510.0 million tonnes in 2020-21 which surpasses the global rice production by 1.6 percent (FAO, 2020). Therefore, for global food security there is an urgent need to augment the global rice production in a sustainable manner. 
Phosphate solubilizing bacteria (PSB) are the promising microorganisms that colonize the rhizospheric region in the soil and promote the growth and yield of crops by enhancing phosphorus (P) accessibility to plants from soil (Tomer et al., 2016). Bacteria belonging to genera Bacillus, Pantoea, Enterobacter, Serratia, Pseudomonas, Chryseobacterium, Rhodococcus, Arthrobacter,Staphylococcus, Rahnella, and Burkholderia are some efficient phosphate solubilizers (Rawat et al., 2020). PSB also produce plant growth promoting compounds viz., growth hormones, organic acids, exopolysaccharides, 1aminocyclopropane-1-carboxylic acid deaminase, siderophores, antioxidants and secondary metabolites that improves environmental stress resistance mechanisms in plants.

These microorganisms induce systemic resistance in host plant and also produce antifungal and antibacterial compounds like polyketides, terpenoids, peptaibols, pyrrolnitrin, daucans, phenazines, and antibiotics which are antagonistic to plant pathogens (Khadeejath Rajeela et al., 2018). Application of PSB in soil as biofertilizers is a powerful substitute for agrochemicals without the negative socio-economic and environmental consequences and are suitable for sustainable agricultural practices as agrochemical based cropping system is hazardous to the environment and human health.

Various experiments are available in literature which have accentuated the beneficial impact of phosphate solubilizing rhizobacteria on growth and disease suppression in diverse crops (Suleman et al., 2018). The present study was performed to evaluate the effect of PSB isolated from rice rhizosphere on growth attributes and biocontrol of pathogens in rice under field conditions.

\section{Materials and Methods}

Two year field experiment was performed at Dr. Norman E. Borlaug Crop Research Centre and Department of Plant Physiology, College of Basic Sciences and Humanities, Govind Ballabh Pant University of Agriculture \& Technology, Pantnagar, (Uttarakhand) during the Kharif season of 2018 and 2019. The rice genotype Pant Dhan 26 was used for the experiment. The field site was laid out in split-plot design with three replications of each treatment. The gross plot size was $30 \mathrm{~m}$ X $24.5 \mathrm{~m}$. Three PSB strains were isolated from rice rhizosphere viz., PSB1, PSB2, and PSB3.

The seeds were bacterized and directly sown in the field with rainfed conditions without excessive irrigation. The crop was grown in the field under nine treatments as - T1: Uninoculated control with phosphate fertilizer doses viz., $0 \%, 50 \%, 75 \%, 100 \%$ of recommended dose (45 $\left.\mathrm{kg} \mathrm{ha}^{-1}\right)$, T2: PSB 1, T3: PSB 2; T4: PSB 3, T5: PSB $1+$ PSB 2; T6: PSB 1+ PSB 3; T7: PSB 2 + PSB 3; T8: PSB $1+$ PSB $2+$ PSB; T9: Standard PSB strain.

For plant sampling and analysis, rice plants from each plot were selected at flowering and maturity, observations such as stem weight, leaf weight, and tiller number were recorded for both the years. The $\mathrm{P}$ content was estimated in dried samples using standard protocols by Jackson (1962). Disease and pest infestation in plants viz., leaf folder, stem borer, and blast were evaluated at flowering by the method of Ning et al., (2014) and the percentage of infested plants were calculated as

$$
\text { Infested plants }(\%)=\frac{\text { Number of infested plants in a plot }}{\text { Total number of plants in a plot }} \times 100
$$

The data was subjected to two-way analysis of variance (ANOVA) by using SPSS ver. 
16.0 statistical software followed by test at a significance level of $\mathrm{p}<0.05$.

\section{Results and Discussion}

\section{Growth parameters}

The data in Table $1 \mathrm{a}$ and $1 \mathrm{~b}$ represents the stem weight and leaf weight at flowering for the rice under PSB treatment with different phosphate fertilizer doses. The data clearly illustrates that the augmentation in stem and leaf weight for both the years is statistically significant for the PSB treated plants when compared to the control plants under both fertilized and unfertilized conditions. In 2018, for uninoculated control (T1) the maximum stem weight and leaf weight was observed for $100 \%$ phosphate fertilized plants. In PSB treated plants maximum stem weight $(8.48 \mathrm{~g}$ hill $^{-1}$ ) was observed in T8 treatments supplement with $50 \%$ phosphate fertilizer dose with an increase of $87.12 \%$. Likewise, for the year 2019, treatment T8 with 50\% phosphate fertilizer dose showed maximum stem weight $\left(8.55 \mathrm{~g} \mathrm{hill}^{-1}\right)$ with an increment of $93.36 \%$.

Maximum leaf weight $\left(5.19 \mathrm{~g} \mathrm{hill}{ }^{-1}\right)$ was recorded for $\mathrm{T} 8$ treatment followed by $\mathrm{T} 9$ (5.04 $\mathrm{g} \mathrm{hill}^{-1}$ ) blended with $50 \%$ phosphate fertilizer dose with an increment of $116.39 \%$ and $110 \%$, respectively in 2018 .

For the year 2019, highest leaf weight was recorded for T9 $\left(5.27 \mathrm{~g} \mathrm{hill}^{-1}\right)$ followed by T8 $\left(5.17 \mathrm{~g} \mathrm{hill}^{-1}\right)$ treatment in combination with $50 \%$ phosphate fertilizer with an increment of $142.70 \%$ and $138.25 \%$, respectively.

The data illustrated in Figure 1a and Figure $1 \mathrm{~b}$ elucidates impact of PSB inoculation on productive tiller numbers per hill for both the cropping years. A significant increment in productive tiller number per hill was recorded in all the PSB treated plants compared to uninoculated control. Maximum number of productive tillers $(7.67,7.80)$ was recorded in treatment T8 supplemented with 50\% phosphatic fertilizer with an increase of $108.90 \%$ and $77.06 \%$ in 2018 and 2019, respectively.

Our data reveals that PSB treatment without any phosphate source enhanced the growth attributes which were comparable to fertilized treatment only. Increment in stem dry weight, leaf dry weight, and productive tiller number might be due to enhanced phosphorus supply to the plants by the PSB action like solubilization of inorganic phosphorus in soil through the production of phosphatases, phytases enzymes, organic acids, and siderophores (Yu et al., 2011; Suleman et al., 2018). Production of plant growth regulation hormones like indole acetic acid, cytokinins, and gibberellins is also major factor for increment in growth attributes in plants (Rafique et al., 2017). Phosphorus is perceived to be an important component for the biosynthesis of phospholipids for cell membrane, adenosine triphosphate, deoxyribonucleic acid, and phosphorylation of photosynthetic proteins which significantly enhances plant growth and development (Zer and Ohad, 2003). Productive tiller number are considered as an important yield parameter as it plays a role in determining the grain bearing panicles.

Improvement in productive tiller numbers, shoot dry matter in PSB treated plants have been reported in Gurdeep and Reddy (2015) which may be attributed to importance of phosphorus role in cell division also. Furthermore, $50 \%$ phosphate fertilizer rate was found to be optimum compare to higher fertilization rates which might be attributes to nutritional imbalance and accumulation of high salts in soil due to high phosphate fertilization rates. 
Table.1a Effect of PSB and different phosphate fertilizer doses on growth attributes in rice at flowering during cropping year 2018. \pm indicates standard error of mean. Means followed by different letters in the column are significantly different

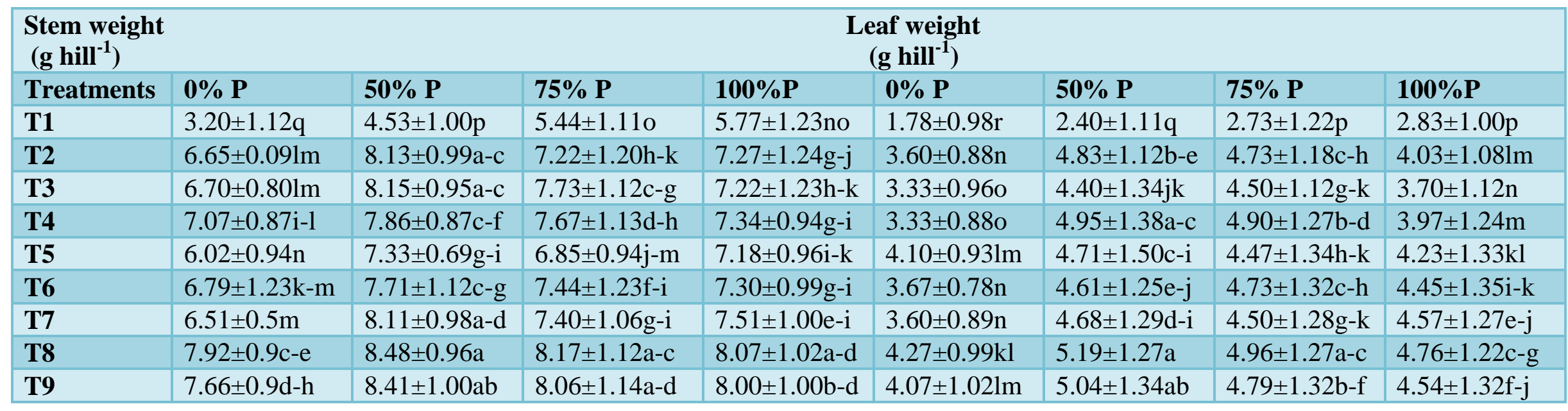

Table.1b Effect of PSB and different phosphate fertilizer doses on growth attributes in rice at flowering during cropping year 2019. \pm indicates standard error of mean. Means followed by different letters in the column are significantly different

\begin{tabular}{|c|c|c|c|c|c|c|c|c|}
\hline \multirow{2}{*}{$\begin{array}{l}\text { Stem weight } \\
\left(\text { g hill }^{-1}\right) \\
\text { Treatments }\end{array}$} & \multicolumn{8}{|c|}{ (g hill-1) } \\
\hline & $0 \% \mathbf{P}$ & $50 \% \mathrm{P}$ & $75 \% P$ & $100 \% \mathrm{P}$ & $0 \% \mathbf{P}$ & $50 \% \mathbf{P}$ & $75 \% P$ & $100 \% \mathrm{P}$ \\
\hline T1 & $3.97 \pm 1.22 q$ & $4.42 \pm 1.22 p$ & $5.77 \pm 1.660$ & $5.90 \pm 1.220$ & $1.78 \pm 1.65 n$ & $2.17 \pm 1.88 \mathrm{~m}$ & $2.67 \pm 1.821$ & $2.93 \pm 1.76 \mathrm{k}$ \\
\hline $\mathbf{T} 2$ & $6.68 \pm 1.45 \mathrm{mn}$ & $8.39 \pm 1.67 \mathrm{ab}$ & $7.24 \pm 1.26 \mathrm{i}-1$ & $7.53 \pm 1.26 f-j$ & $3.53 \pm 1.45 \mathrm{j}$ & $4.97 \pm 1.54 b c$ & $4.63 \pm 1.23 \mathrm{~d}-\mathrm{f}$ & $4.18 \pm 1.26 \mathrm{hi}$ \\
\hline T3 & $6.56 \pm 1.76 \mathrm{mn}$ & $8.05 \pm 1.45 b-d$ & $7.15 \pm 1.54 \mathrm{j}-1$ & $7.34 \pm 1.34 \mathrm{~h}-\mathrm{k}$ & $3.40 \pm 1.44 \mathrm{j}$ & $4.63 \pm 1.64 d-f$ & $4.39 \pm 1.10 \mathrm{f}-\mathrm{h}$ & $4.11 \pm 1.38 \mathrm{hi}$ \\
\hline T4 & $6.88 \pm 1.561 \mathrm{~m}$ & $8.16 \pm 1.98 \mathrm{a}-\mathrm{c}$ & $7.41 \pm 1.22 \mathrm{~g}-\mathrm{j}$ & $7.39 \pm 1.56 \mathrm{~g}-\mathrm{j}$ & $3.60 \pm 1.73 \mathrm{j}$ & $5.07 \pm 1.34 \mathrm{a}-\mathrm{c}$ & $4.27 \pm 1.12 \mathrm{gh}$ & $4.27 \pm 1.45 \mathrm{gh}$ \\
\hline T5 & $6.41 \pm 0.77 n$ & $7.75 \pm 1.67 \mathrm{c}-\mathrm{h}$ & $7.63 \pm 1.27 \mathrm{~d}-\mathrm{i}$ & $6.93 \pm 1.65 \mathrm{k}-\mathrm{m}$ & $3.97 \pm 1.45 \mathrm{i}$ & $5.13 \pm 1.44 \mathrm{ab}$ & $4.57 \pm 1.65 \mathrm{ef}$ & $4.52 \pm 1.34 \mathrm{e}-\mathrm{g}$ \\
\hline T6 & $6.55 \pm 1.65 \mathrm{mn}$ & $7.81 \pm 1.45 \mathrm{c}-\mathrm{g}$ & $7.49 \pm 1.20 \mathrm{f}-\mathrm{j}$ & $7.56 \pm 1.76 e-j$ & $3.47 \pm 1.39 \mathrm{j}$ & $4.78 \pm 1.56 c-e$ & $4.53 \pm 1.43 \mathrm{e}-\mathrm{g}$ & $4.18 \pm 1.76 \mathrm{hi}$ \\
\hline $\mathbf{T 7}$ & $6.55 \pm 1.50 \mathrm{mn}$ & $8.03 \pm 1.32 b-d$ & $7.49 \pm 1.32 \mathrm{f}-\mathrm{j}$ & $7.83 \pm 1.34 \mathrm{c}-\mathrm{g}$ & $3.33 \pm 1.52 \mathrm{j}$ & $4.57 \pm 1.49 \mathrm{ef}$ & $4.63 \pm 1.33 \mathrm{~d}-\mathrm{f}$ & $4.54 \pm 1.29 \mathrm{e}-\mathrm{g}$ \\
\hline T8 & $7.41 \pm 1.34 \mathrm{~g}-\mathrm{j}$ & $8.55 \pm 1.23 \mathrm{a}$ & $8.13 \pm 1.33 \mathrm{a}-\mathrm{c}$ & $8.00 \pm 1.21 \mathrm{~b}-\mathrm{e}$ & $4.53 \pm 1.58 \mathrm{e}-\mathrm{g}$ & $5.17 \pm 1.34 \mathrm{ab}$ & $4.90 \pm 1.27 \mathrm{~b}-\mathrm{d}$ & $4.97 \pm 1.33 b c$ \\
\hline T9 & $7.28 \pm 1.38 \mathrm{i}-1$ & $8.41 \pm 1.65 \mathrm{ab}$ & $8.11 \pm 1.34 \mathrm{a}-\mathrm{c}$ & $7.93 \pm 1.22 \mathrm{c}-\mathrm{f}$ & $4.27 \pm 1.62 \mathrm{gh}$ & $5.27 \pm 1.33 \mathrm{a}$ & $4.91 \pm 1.41 \mathrm{~b}-\mathrm{d}$ & $4.90 \pm 1.78 b-d$ \\
\hline
\end{tabular}


Table.2a Effect of PSB and different phosphate fertilizer doses on pest infestation in rice at flowering during cropping year 2018. \pm indicates standard error of mean. Means followed by different letters in the column are significantly different

\begin{tabular}{|c|c|c|c|c|c|c|c|c|}
\hline \multicolumn{5}{|c|}{$\begin{array}{c}\text { Stem Borer Infestation } \\
(\%)\end{array}$} & \multicolumn{4}{|c|}{$\begin{array}{c}\text { Leaf Folder Infestation } \\
(\%)\end{array}$} \\
\hline Treatments & $\mathbf{0 \%} \mathrm{P}$ & $50 \% \mathrm{P}$ & $75 \% \mathrm{P}$ & $100 \% \mathrm{P}$ & $\mathbf{0 \%} \mathbf{P}$ & $50 \% P$ & $75 \% \mathrm{P}$ & $100 \% P$ \\
\hline T1 & $20.42 \pm 0.87 a$ & $15.42 \pm 1.24 b$ & $15.42 \pm 1.05 b$ & $18.75 \pm 1.11 \mathrm{a}$ & $18.75 \pm 0.94 a$ & $10.42 \pm 1.02 \mathrm{ef}$ & $8.96 \pm 0.82 f-h$ & $17.50 \pm 0.87 \mathrm{a}$ \\
\hline $\mathbf{T} 2$ & $13.75 \pm 0.96 b c$ & $6.67 \pm 1.201-p$ & $7.08 \pm 1.04 \mathrm{k}-\mathrm{o}$ & $9.58 \pm 1.16 f-j$ & $14.58 \pm 0.87 b$ & $5.63 \pm 0.93 \mathrm{k}-\mathrm{m}$ & $6.46 \pm 0.73 \mathrm{j}-1$ & $14.58 \pm 0.93 b$ \\
\hline T3 & $8.75 \pm 0.94 \mathrm{j}-1$ & $5.00 \pm 0.88$ op & $7.50 \pm 1.00 \mathrm{j}-\mathrm{n}$ & $8.75 \pm 1.65 \mathrm{j}-1$ & $12.08 \pm 1.13 \mathrm{~d}$ & $3.54 \pm 0.98 \mathrm{n}$ & $4.79 \pm 0.931-n$ & $9.58 \pm 0.77 f g$ \\
\hline $\mathbf{T 4}$ & $13.33 \pm 0.76 b-d$ & $9.17 \pm 0.94 \mathrm{f}-\mathrm{k}$ & $10.00 \pm 1.14 \mathrm{e}-\mathrm{i}$ & $11.25 \pm 1.34 \mathrm{~d}-\mathrm{f}$ & $12.08 \pm 1.23 \mathrm{~d}$ & $4.38 \pm .88 \mathrm{mn}$ & $6.46 \pm 0.76 \mathrm{j}-1$ & $9.58 \pm 0.90 \mathrm{fg}$ \\
\hline T5 & $11.25 \pm 0.91 \mathrm{~d}-\mathrm{f}$ & $7.08 \pm 0.92 \mathrm{k}-\mathrm{o}$ & $10.42 \pm 1.23 \mathrm{e}-\mathrm{h}$ & $10.00 \pm 1.54 \mathrm{e}-\mathrm{i}$ & $14.17 \pm 1.54 b$ & $4.38 \pm 1.12 \mathrm{mn}$ & $4.79 \pm 0.881-n$ & $12.08 \pm 0.92 \mathrm{~d}$ \\
\hline T6 & $11.25 \pm 1.10 \mathrm{~d}-\mathrm{f}$ & $7.08 \pm 1.00 \mathrm{k}-\mathrm{o}$ & $12.08 \pm 1.15 c-e$ & $10.83 \pm 1.32 \mathrm{e}-\mathrm{g}$ & $13.75 \pm 1.34 b c$ & $6.46 \pm 0.98 \mathrm{j}-1$ & $7.08 \pm 0.78 \mathrm{i}-\mathrm{k}$ & $13.75 \pm 1.12 b c$ \\
\hline T7 & $9.58 \pm 1.12 f-j$ & $5.42 \pm 1.05 n-p$ & $7.92 \pm 1.22 \mathrm{i}-\mathrm{m}$ & $7.08 \pm 1.22 \mathrm{k}-\mathrm{o}$ & $11.25 \pm 1.22 \mathrm{de}$ & $5.63 \pm 1.12 \mathrm{k}-\mathrm{m}$ & $6.46 \pm 0.85 \mathrm{j}-1$ & $12.50 \pm 1.02 \mathrm{~cd}$ \\
\hline T8 & $7.50 \pm 1.00 \mathrm{j}-\mathrm{n}$ & $4.58 \pm 0.98 p$ & $6.25 \pm 1.65 \mathrm{~m}-\mathrm{p}$ & $6.67 \pm 1.531-p$ & $8.33 \pm 1.54 \mathrm{~g}-\mathrm{i}$ & $3.13 \pm 1.00 \mathrm{n}$ & $4.17 \pm 0.93 \mathrm{mn}$ & $7.92 \pm 1.03 \mathrm{~h}-\mathrm{j}$ \\
\hline T9 & $8.33 \pm 0.95 \mathrm{~h}-\mathrm{m}$ & $4.56 \pm-0.97 p$ & $7.92 \pm 1.23 \mathrm{i}-\mathrm{m}$ & $7.08 \pm 1.23 \mathrm{k}-\mathrm{o}$ & $10.00 \pm 1.22 \mathrm{ef}$ & $3.96 \pm 1.02 \mathrm{mn}$ & $4.38 \pm 1.07 \mathrm{mn}$ & $7.92 \pm 1.12 \mathrm{~h}-\mathrm{j}$ \\
\hline
\end{tabular}

Table.2b Effect of PSB and different phosphate fertilizer doses on pest infestation in rice at flowering during cropping year 2019. \pm indicates standard error of mean. Means followed by different letters in the column are significantly different

\begin{tabular}{|c|c|c|c|c|c|c|c|c|}
\hline \multicolumn{4}{|c|}{$\begin{array}{c}\text { Stem Borer Infestation } \\
(\%)\end{array}$} & \multicolumn{5}{|c|}{$\begin{array}{c}\text { Leaf Folder Infestation } \\
(\%)\end{array}$} \\
\hline Treatments & $0 \% \mathrm{P}$ & $50 \% P$ & $75 \% P$ & $100 \% P$ & $0 \% \mathbf{P}$ & $50 \% \mathrm{P}$ & $75 \% P$ & $100 \% \mathrm{P}$ \\
\hline T1 & $22.50 \pm 0.67 \mathrm{a}$ & $16.75 \pm 1.05 b c$ & $16.50 \pm 0.98 b c$ & $17.50 \pm 0.89 b$ & $17.72 \pm 0.78 \mathrm{a}$ & $12.82 \pm 1.06 \mathrm{e}-\mathrm{g}$ & $14.72 \pm 1.11 b c$ & $18.66 \pm 1.12 \mathrm{a}$ \\
\hline $\mathbf{T} 2$ & $14.50 \pm 0.58 \mathrm{~cd}$ & $7.25 \pm 1.03 \mathrm{k}-\mathrm{m}$ & $8.50 \pm 0.96 \mathrm{i}-1$ & $11.50 \pm 0.92 \mathrm{e}-\mathrm{h}$ & $15.11 \pm 0.92 b c$ & $10.62 \pm 1.12 \mathrm{ij}$ & $11.83 \pm 0.92 \mathrm{f}-\mathrm{i}$ & $14.58 \pm 1.32 b-d$ \\
\hline T3 & $11.50 \pm 0.88 \mathrm{e}-\mathrm{h}$ & $8.00 \pm 1.12 \mathrm{i}-1$ & $10.00 \pm 1.12 \mathrm{f}-\mathrm{j}$ & $9.58 \pm 1.10 \mathrm{~g}-\mathrm{k}$ & $15.92 \pm 1.10 \mathrm{~b}$ & $11.72 \pm 1.15 \mathrm{~g}-\mathrm{i}$ & $12.23 \pm 1.03 \mathrm{f}-\mathrm{h}$ & $13.23 \pm 1.26 \mathrm{~d}-\mathrm{f}$ \\
\hline T4 & $14.58 \pm 0.69 \mathrm{~cd}$ & $10.00 \pm 1.15 f-j$ & $11.83 \pm 1.02 \mathrm{e}-\mathrm{g}$ & $11.83 \pm 1.12 \mathrm{e}-\mathrm{g}$ & $14.84 \pm 1.12 b c$ & $9.78 \pm 1.23 \mathrm{jk}$ & $11.11 \pm 1.12 \mathrm{~h}-\mathrm{j}$ & $13.23 \pm 1.11 \mathrm{~d}-\mathrm{f}$ \\
\hline T5 & $13.50 \pm 0.89 \mathrm{de}$ & $9.00 \pm 1.23 \mathrm{~h}-\mathrm{k}$ & $11.42 \pm 0.88 \mathrm{e}-\mathrm{h}$ & $11.50 \pm 1.45 \mathrm{e}-\mathrm{h}$ & $15.67 \pm 0.92 b$ & $8.27 \pm 0.891 \mathrm{~m}$ & $12.73 \pm 1.05 \mathrm{e}-\mathrm{g}$ & $13.87 \pm 1.20 \mathrm{c}-\mathrm{e}$ \\
\hline T6 & $14.50 \pm 0.92 \mathrm{~cd}$ & $11.50 \pm 1.56 \mathrm{e}-\mathrm{h}$ & $12.25 \pm 1.11 \mathrm{~d}-\mathrm{f}$ & $12.50 \pm 1.22 \mathrm{~d}-\mathrm{f}$ & $14.75 \pm 1.16 b c$ & $7.56 \pm 1.00 \mathrm{mn}$ & $10.50 \pm 0.88 \mathrm{ij}$ & $13.28 \pm 1.16 \mathrm{~d}-\mathrm{f}$ \\
\hline T7 & $11.50 \pm 0.97 \mathrm{e}-\mathrm{h}$ & $7.50 \pm 1.23 \mathrm{j}-\mathrm{m}$ & $10.00 \pm 1.13 \mathrm{f}-\mathrm{j}$ & $10.50 \pm 1.14 \mathrm{f}-\mathrm{i}$ & $13.72 \pm 0.89 c-e$ & $6.64 \pm 1.03 \mathrm{no}$ & $11.73 \pm 0.92 \mathrm{~g}-\mathrm{i}$ & $12.98 \pm 1.15 \mathrm{e}-\mathrm{g}$ \\
\hline T8 & $10.00 \pm 1.03 f-j$ & $5.50 \pm 1.26 \mathrm{~m}$ & $8.50 \pm 0.94 \mathrm{i}-1$ & $9.50 \pm 1.25 \mathrm{~g}-\mathrm{k}$ & $10.73 \pm 1.23 \mathrm{ij}$ & $5.32 \pm 1.210$ & $8.60 \pm 1.23 \mathrm{k}-\mathrm{m}$ & $9.06 \pm 1.53 \mathrm{kl}$ \\
\hline T9 & $9.08 \pm 1.04 \mathrm{~h}-\mathrm{k}$ & $6.50 \pm 1.02 \mathrm{~lm}$ & $8.17 \pm 0.92 \mathrm{i}-1$ & $9.50 \pm 1.18 \mathrm{~g}-\mathrm{k}$ & $11.67 \pm 1.16 \mathrm{~g}-\mathrm{i}$ & $5.84 \pm 1.00 \mathrm{o}$ & $9.06 \pm 1.43 \mathrm{kl}$ & $9.01 \pm 1.00 \mathrm{kl}$ \\
\hline
\end{tabular}


Fig.1 Effect of PSB and different phosphate fertilizer doses on the number of productive tillers in rice at flowering during cropping year 2018 (a) and 2019 (b). \pm indicates standard error of mean.

Means followed by different letters in the bars are significantly different

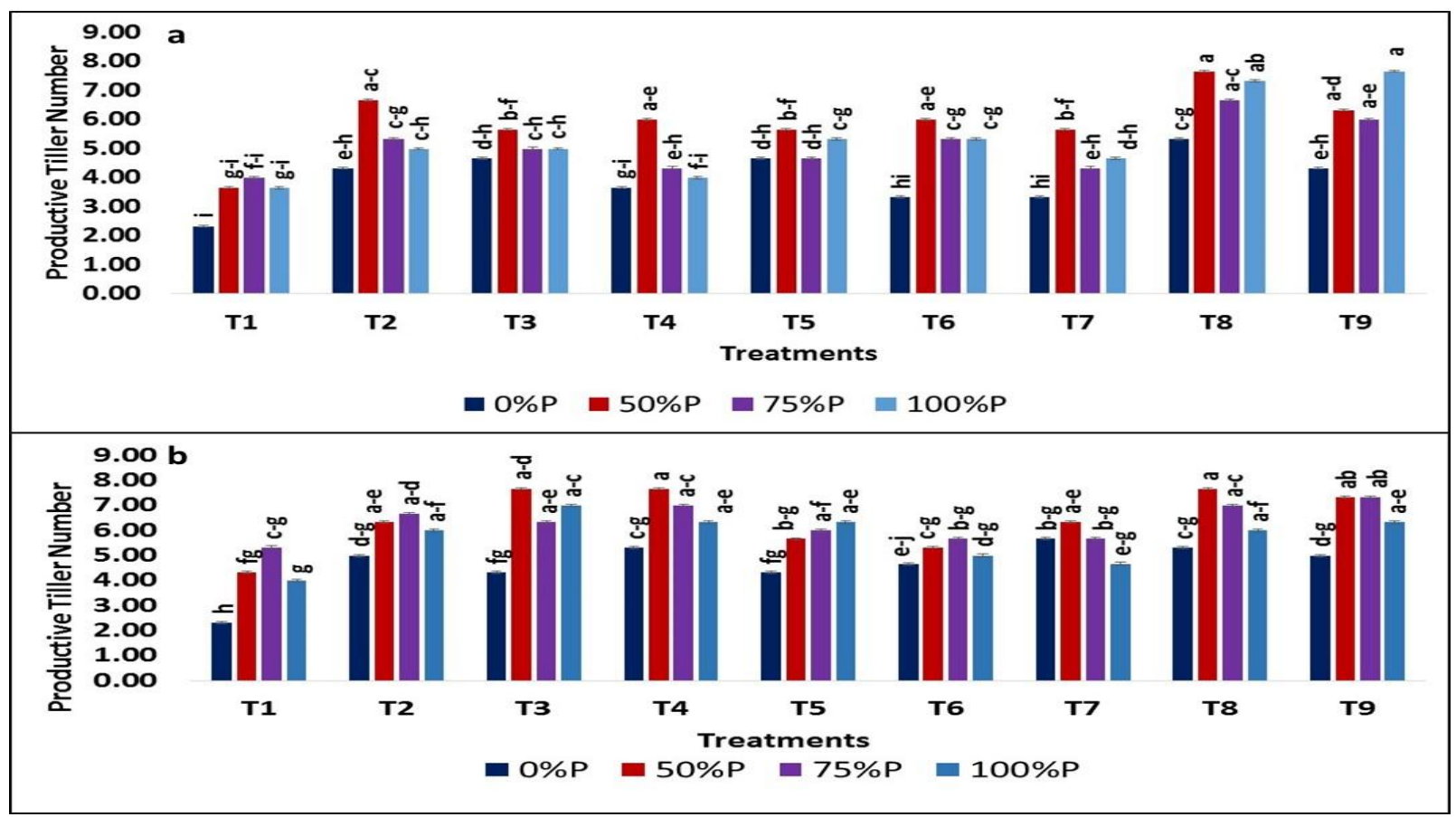

\section{Biocontrol efficiency}

Data represented in Table $2 \mathrm{a}$ and $2 \mathrm{~b}$ depicts the effect of PSB treatment and phosphate fertilization in stem borer and leaf folder incidence in rice plants. A significant reduction in pest infestation in rice was observed in all the PSB treated plants compared to uninoculated plants in 2018 and 2019. In 2018, minimum incidence of stem borer infestation $(4.58 \%)$ was observed in $\mathrm{T} 8$ treatment in combination with $50 \%$ fertilization rates compared to its respective control plants $(15.42 \%)$ with a reduction of 70.28\%. Likewise, in 2019 minimum incidence of stem borer infestation $(5.50 \%)$ was reported in $\mathrm{T} 8$ treatment blended with $50 \%$ fertilization rates compared its respective control $(16.75 \%)$ with a reduction of $67.16 \%$. Maximum incidence of stem borer infestation (20.42\% and $22.50 \%$ ) was observed in control plants without phosphate fertilization in 2018 and 2019, respectively.
In 2018, minimum incidence of leaf folder infestation $(3.13 \%)$ was observed in $\mathrm{T} 8$ treatment in combination with $50 \%$ fertilization rates compared to its respective control plants $(10.42 \%)$ with a reduction of 70.01\%. Likewise, in 2019 minimum incidence of leaf folder infestation (5.32\%) was reported in T8 treatment blended with $50 \%$ fertilization rates compared its respective control $(12.82 \%)$ with a reduction of $58.54 \%$. Maximum incidence of leaf folder infestation (18.75\% and $18.66 \%$ ) was observed in control plants without phosphate fertilization and control plants with $100 \%$ phosphate fertilization in 2018 and 2019, respectively.

Many PSB are reported to be potent biocontrol agents. These microorganisms produce hydrogen cyanide which is toxic to the insects and pathogens. Production of antibiotics, and defense related enzymes viz., proteases, amylases, glucanases, and chitinases by the microorganisms are 
antagonistic agents that inhibits the metabolic machinery of the pathogens and lowers the disease incidence in host plants (Bardin et al., 2015). Moreover induction of induced systemic resistance in host plants by the inoculated plant growth promoting PSB is another factor which contributes towards the biological control of the plants against the pathogens (Chithrashree et al., 2011).

Application of PSB in rice is an effective strategy to improve the growth, health, and nutritional balance in rice plants. Inoculation of PSB in combination with agrochemical phosphorus reduced the dose of fertilizer application and is a potent strategy for sustainable cropping system. Therefore, further research should be conducted to discover new PSB and implement the PSB in diverse cropping system for a healthy crop yield.

\section{Acknowledgment}

The authors are thankful to Department of Plant Physiology, G.B. Pant University of Agriculture and Technology, India for providing the necessary materials for the research. We are also grateful to the AICRP, ICAR New Delhi, India for providing necessary facilities during the field study.

\section{References}

Bardin, M., Ajouz, S., Comby, M., LopezFerber, M., Graillot, B., Siegwart, M. and Nicot, P. C. 2015. Is the efficacy of biological control against plant diseases likely to be more durable than that of chemical pesticides? Front Plant Sci., 6: 566.

Chithrashree Udayashankar, A. C., Chandra, N. S., Reddy, M. S. and Srinivas, C. 2011. Plant growth-promoting rhizobacteria mediate induced systemic resistance in rice against bacterial leaf blight caused by Xanthomonas oryzae pv. oryzae. Biol. Control, 59: 114-122

FAO 2018. World Food and Agriculture Statistical Pocketbook 2018. Rome. http://www.fao.org/3/CA1796EN/ca179 6en.pdf. Accessed 23 October 2018.

FAO 2019. The State of Food and Agriculture. Moving forward on food loss and waste reduction. Rome. http://www.fao.org/3/ca6030en/ca6030e n.pdf. Accessed 12 June 2019

Food and Agriculture Organization of the United Nations 2020. Food and agriculture data. Food and agriculture organization of the United Nations FAOSTAT. https ://www.fao.org/faost at/en/\#home. Accessed 9 Jan 2020

Gurdeep, K.A.U.R. and Reddy, M.S. 2015. Effects of phosphate-solubilizing bacteria, rock phosphate and chemical fertilizers on maize-wheat cropping cycle and economics. Pedosphere, 25: 428-437.

IRRI 2006. Bringing hope, improving livesstrategies. Plan 2007-2015. International Rice Research Institute, Los Banos, pp.61

Jackson, M.L. 1962. Soil Chemical Analysis. Prentice Hall, Inc. Eaglewood Cliffs, New York.

Khadeejath Rajeela, T. H., Gupta, A., Gopal, M., Hegde, V. and Thomas, G. V. 2018. Evaluation of combinatorial capacity of coconut and cocoa plant growth promoting rhizobacteria (PGPR) with biocontrol agent Trichoderma harzianum. Curr Investig Agric Curr, Res, 3: 404-409.

Ning, D., Song, A., Fan, F., Li, Z. and Liang, Y. 2014. Effects of slag-based silicon fertilizer on rice growth and brown-spot resistance. PLoS One, 9: e102681.

Rafique, M., Sultan, T., Ortas, I. and Chaudhary, H. J. 2017. Enhancement of maize plant growth with inoculation of 
phosphate-solubilizing bacteria and biochar amendment in soil. Soil Sci Plant Nutr, 63: 460-469.

Rawat, P., Shankhdhar, D. and Shankhdhar, S.C. 2020. Plant Growth-Promoting Rhizobacteria: A Booster for Ameliorating Soil Health and Agriculture Production. In: Giri, B., Verma, A. (eds) Soil Health. Springer, Cham, pp 47-68.

Suleman, M., Yasmin, S., Rasul, M., Yahya, M., Atta, B. M. and Mirza, M. S. 2018. Phosphate solubilizing bacteria with glucose dehydrogenase gene for phosphorus uptake and beneficial effects on wheat. PloS one, 13: 1-28.

Tomer, S., Suyal, D. C. and Goel, R. 2016. Biofertilizers: A Timely Approach for
Sustainable Agriculture, in Choudhary, D., Varma, A., Tuteja, N. (eds.) PlantMicrobe Interaction: An Approach to Sustainable Agriculture. Springer, Singapore, pp 375-395.

Yu, X., Liu, X., Zhu, T. H., Liu, G. H. and Mao, C. 2011. Isolation and characterization of phosphatesolubilizing bacteria from walnut and their effect on growth and phosphorus mobilization. Biol. Fertil. Soil, 47: 437446.

Zer, H. and Ohad, I. 2003. Light, redox state, thylakoid-protein phosphorylation and signaling gene expression. Trends BiochemSci, 28: 467-470.

\section{How to cite this article:}

Pratibha Rawat, Deepti Shankhdhar and Shankhdhar, S. C. 2020. Plant Growth Promoting Potential and Biocontrol Efficiency of Phosphate Solubilizing Bacteria in Rice (Oryza sativa L.). Int.J.Curr.Microbiol.App.Sci. 9(09): 2145-2152. doi: https://doi.org/10.20546/ijcmas.2020.909.267 